\title{
Differential impacts of ridesharing on alcohol-related crashes by socioeconomic municipalities: rate of technology adoption matters
}

\author{
Carola Blazquez ${ }^{1}$, José Guillermo Cedeño Laurent ${ }^{2}$ and José Ignacio Nazif-Munoz ${ }^{2,3^{*}}$
}

\begin{abstract}
Background: An emergent group of studies have examined the extent under which ridesharing may decrease alcohol-related crashes in countries such as United States, United Kingdom, Brazil, and Chile. Virtually all existent studies have assumed that ridesharing is equally distributed across socioeconomic groups, potentially masking differences across them. We contribute to this literature by studying how socioeconomic status at the municipal level impacts Uber's effect on alcohol-related crashes.

Methods: We use data provided by Chile's Road Safety Commission considering all alcohol-related crashes, and fatal and severe alcohol-related injuries that occurred between January 2013 and September 2013 (before Uber) and January and September 2014 (with Uber) in Santiago. We first apply spatial autocorrelation techniques to examine the level of spatial dependence between the location of alcohol-related crashes with and without Uber. We then apply random-effects meta-analysis to obtain risk ratios of alcohol-related crashes by considering socioeconomic municipality differences before and after the introduction of Uber.

Results: In both analyses, we find that the first 9 months of Uber in Santiago is associated with significant rate ratio decreases (RR $=0.71$ [95\% Confidence Interval (C.I.) $0.56,0.89]$ ) in high socioeconomic municipalities in all alcoholrelated crashes and null (RR $=1.10[95 \%$ C.I. 0.97, 1.23]) increases in low socioeconomic municipalities. No concomitant associations were observed in fatal alcohol-related crashes regardless of the socioeconomic municipality group.

Conclusions: One interpretation for the decline in alcohol-related crashes in high socioeconomic municipalities is that Uber may be a substitute form of transport for those individuals who have access to credit cards, and thus, could afford to pay for this service at the time they have consumed alcohol. Slight increases of alcohol-related crashes in low socioeconomic municipalities should be studied further since this could be related to different phenomena such as increases in alcohol sales and consumption, less access to the provision of public transport services in these jurisdictions, or biases in police reports.
\end{abstract}

Keywords: Uber, Road safety, Alcohol, Socioeconomic groups

\footnotetext{
* Correspondence: jose.ignacio.nazif-munoz@usherbrooke.ca

${ }^{2}$ Department of Environmental Health, Harvard T.H. Chan School of Public Health, 677 Huntington Avenue, Boston, MA 02115, USA

3Université de Sherbrooke, Faculté de médecine et des sciences de la santé,

150, place Charles-Le Moyne, Longueuil, QC J4K 0A8, Canada

Full list of author information is available at the end of the article
}

(c) The Author(s). 2021 Open Access This article is licensed under a Creative Commons Attribution 4.0 International License, which permits use, sharing, adaptation, distribution and reproduction in any medium or format, as long as you give appropriate credit to the original author(s) and the source, provide a link to the Creative Commons licence, and indicate if changes were made. The images or other third party material in this article are included in the article's Creative Commons licence, unless indicated otherwise in a credit line to the material. If material is not included in the article's Creative Commons licence and your intended use is not permitted by statutory regulation or exceeds the permitted use, you will need to obtain permission directly from the copyright holder. To view a copy of this licence, visit http://creativecommons.org/licenses/by/4.0/ The Creative Commons Public Domain Dedication waiver (http://creativecommons.org/publicdomain/zero/1.0/) applies to the data made available in this article, unless otherwise stated in a credit line to the data. 


\section{Background}

Ridesharing, a service that connects drivers with potential passengers through a mobile application, is a type of technological innovation, which has shown a remarkable case of diffusion and convergence across and within transport systems. For instance, Uber, one of many ridesharing application providers, has since 2011 spread to at least 900 cities in 84 countries, and during 2018 it supplied over 10 billion trips globally [1]. In the Middle East, North Africa, and South Asia, Careem has spread to more than 50 cities [2]. In United States, Lyft operates in more than 300 cities, and in China, DiDi Chuxing is used by more than 450 million users, and spread to more than 400 cities [3].

The understanding of the multifaceted impacts of ridesharing however requires a theoretical understanding of how and why this type of services successfully diffuse within transport systems. The theory of diffusion innovations [4] has been used to explain the adoption of ideas and technologies in different realms including among others, science, policies, marketing, and transport $[5,6]$. This theory describes how in a given community during a specific period, members are likely to adopt a similar device (convergence), which responds to a specific unmet need. Convergence however may be slow but also may not occur at all. Indeed, social networks, whereby technologies or ideas are channelled, can impede spreading. This may be because the innovation is not properly communicated or understood, does not match a need, or means to adopt it are not yet available $[7,8]$. Considerable part of diffusion of innovation research has focused on classifying what makes individuals to adopt before convergence could be observed. Broadly, when an innovation has finally spread, five overlapping groups of users could be identified: innovators, early adopters, early majority, late adopters and laggards or sceptics [9].

The functioning of transport systems can be positively or negatively altered depending on how rapidly transport providers and/or users accept new technological innovations [10]. This has been the case for instance of mobile ticketing service in public transport [11], models of bike sharing [12], alternative fuel vehicles [13], seat belts [14] or child restraints [15]. Ultimately, the introduction of these technologies can be associated with less polluted environments after alternative fuel vehicles cope the market [16], or considerable decreases in traffic fatalities after seat belts or child restrains are both massively and properly used [17-19]. Yet, the adoption and further use of transport-related technologies may not be equally accepted by transport providers or users [20].

Regarding the diffusion of ridesharing applications two elements should be highlighted. First, studies have suggested that early adopters of ridesharing are both highly educated and from high-income households [21-25]. Further, the initial use of this service was associated with ease of payment since trips could be charged to credit cards, which were integrated into cell phone applications [22]. To extend its use, many ridesharing applications have been complemented with in-cash payments [26, 27]. Second, another group of studies have indicated that ridesharing services could be also associated with decreasing of congestion [28], decreasing in public transit use [29], reduction of air quality [30], and declining of alcohol-related crashes [31-36]. More specifically, in terms of alcohol-related crashes variation, it has been argued that ridesharing provides a valuable alternative to drinking and driving when access to public transport is limited (i.e., low frequency of provision during late hours) and/or traditional taxis costs may be unknown (i.e., high fluctuation of prices for similar trips).

Despite the interest in and growth of ridesharing studies and alcohol-related crashes, there is a surprising gap on understanding how changes in the diffusion of ridesharing use could be associated with variation of these outcomes. This is important because part of the literature has reported mixed results. Greenwood and Wattal [32], Peck [33], Morrison et al. [34], and Martin-Buck [37] have indicated reductions in alcohol-related crashes after ridesharing increased over time. Conversely, Brazil and Kirk [31, 38], Dills and Mulholland [39], and NazifMunoz et al. [36] did not observe any change in the occurrence of these crashes, even after exploring potential increments. The absence of significant variation in these former studies possibly mask either short terms associations or changes in specific groups-such as innovators and/or early adopters. However, to better understand ridesharing application associations, it should be acknowledged that the use of this technology follows over time a gradient of socioeconomic status (SES), whereby innovators and early adopters are more likely to belong to high-income groups, and late adopters and laggards may be linked with lower-income groups [21-25]. As such, when ridesharing applications begin emerging in an urban community, transport-related changes would be expected in high-income groups more prominently [40], and then, depending on whether convergence of this application is reached, outcomes at the population level, regardless of the socioeconomic gradient, should be observed.

In this work, we put lens on understanding how the early adoption of one ridesharing model-Uber-in Chile's capital city, Santiago, could be associated with alcohol-related crash variations. Uber was introduced in January of 2014 in Santiago and by 2017, this service was active in 16 new Chilean cities. At that time, in Santiago, more than 35,000 individuals were registered as drivers, more than 1,350,000 individuals used the 
application per day, and initial reports suggested that this service was offered throughout all its municipalities [41]. The case of Santiago is interesting due to the following reasons. First, a previous study [36] has indeed suggested the absence of effects between Uber and alcohol-related traffic crashes in this city. However, this study did not consider adoption pattern differences when assessing the impact of this service. As a result, this study could have masked different effects across Uber users. Early adopters and frequent users of Uber in Chile, however, are from high-income groups [42]. Further, during the first 2 years of Uber's implementation (2014 to 2016), this platform limited its use to credit card holders only [42], but credit cards are not equally distributed across income groups in Chile [43, 44]. Indeed, in this country, individuals at the highest income decile relative to individuals from the lowest decile, have approximately 50 more chances of owning a credit card [45]. This reinforces the notion that high-income individuals were more likely to be Uber users than individuals from lower income groups. Therefore, possible associations between this service, at initial stages, and alcohol-related crashes should consider socioeconomic differences more consistently. Second, in terms of alcohol consumption while no differences across socioeconomic groups are observed regarding heavy drinking and heavy episodic drinking, individuals from higher SES are more likely to drink higher volumes of pure alcohol weekly than any other socioeconomic group [46]. Lastly, Santiago is a highly socially segregated city, its east central sector, made up of seven municipalities, contains more than $80 \%$ of the main population of the richest quintile. Under these characteristics it could be assumed from an ecological perspective that ridesharing in its genesis could be associated with reductions in alcohol-related outcomes in municipalities where highincome individuals inhabit, and no associations would be necessarily observed in municipalities where individuals from lower incomes live.

To fill gaps in this literature, we examine how SES at the municipal level impacts Uber's effect on alcoholrelated crashes in Santiago, Chile by focusing on the slow pace of Uber's implementation during its first 9 months of implementation. We hypothesize that, in municipalities where high-income individuals inhabit, the beginning of Uber operations relative to its absence, would be associated with lower risks of alcohol-involved crashes.

\section{Methods}

Data

The road traffic crash database was requested to the Chile's National Commission of Road Safety (CONASET) through the Transparency Law [47]. Chilean police
(Carabineros de Chile) collect and report the traffic crash data that consists of crash attributes (date, time, location, contributing cause, type of crash, etc.) and information of the involved victims (age, gender, road user type, injury severity, etc.). Police officers indicate whether alcohol was involved or played a role in the occurrence of the crash by detecting the presence of alcohol through the application of breathalysers [48]. The information provided by police officers is registered as "alcohol-related" when the road user involved in the crash has surpassed a blood alcohol concentration level of $0.03 \%$ [49]. We used alcohol-related traffic crashes that occurred in Santiago, Chile, in which the driver, passenger, or pedestrian was under the influence of alcohol at the moment of the crash occurrence. As a result of crashes, victims may be killed or slightly or severely injured. Passengers or pedestrians were also included in the analyses to capture more variability since the period of analysis is relatively short and they can indirectly cause collisions.

We used two outcomes: all alcohol-related crashes, and killed and seriously injured (KSI) alcohol-related victims. In both groups, drivers may be included. We used population information to determine rates in both outcomes. Population information was derived from the National Institute of Statistics [50]. We used this denominator instead of number of vehicles since the introduction of Uber could be associated with increments in this indicator, thus biasing the results.

To analyse the association of Uber with the outcomes, we considered two nine-month periods in both statistical analyses. The first period is between January 1st, 2013 and September 16th, 2013 (before the entry of Uber in Santiago). The second period starts on January 1st, 2014 with Uber's entry and terminates on September 16th, 2014 with the enacted Emilia Law. This law imprisons drunk drivers for 1 year due to causing severe injury or death outcomes in a traffic crash [36]. We chose to limit the second period because other studies [51] have suggested that decreases of alcohol-related traffic crashes could be attributed to the Emilia Law, and therefore, estimating the true effect of ridesharing on the outcomes would become more problematic.

To cluster the 34 municipalities of Santiago according to five socioeconomic groups: High, High-middle, Middle, Middle-low, and Low, we used the methodology developed by the Observatory of Cities-UC [52]. This methodology uses individual survey data representative of each municipality from the National Institute of Statistics and government's administrative data considering the following six dimensions: i) housing and neighbourhood (quality of housing construction, insecurity and street maintenance); ii) sociocultural conditions (social capital and education); iii) business development 
(conditions to invest, number of banks, unemployment, number of hotels); iv) work conditions (income, work contracts, debts, and life costs); v) health (access to health centres and exposure to air pollution); vi) and connectivity and mobility (access to public transport services and internet connection). In supplementary material, we described the socioeconomic classification per municipality.

\section{Spatial statistical analysis}

Spatial autocorrelation is used to examine the level of spatial dependence between features according to their attribute values. Local spatial autocorrelation identifies spatial heterogeneity and distinguishes between spatial clusters of high- and low-value concentrations [53, 54]. The Getis-Ord Gi* statistic has been employed to perform local spatial autocorrelation analysis of road traffic crashes [55-60]. This statistic is expressed by Eq. (1), where $x_{j}$ indicates the crash attribute at location $j, w_{i j}(d)$ is a spatial weight matrix for all locations $j$ within a threshold distance $d$ from the crash at location $i, n$ is the total number of locations, and $\bar{x}$ and $S$ are the mean and standard deviation, respectively.

$$
G_{i}^{*}(d)=\frac{\sum_{j=1}^{n} w_{i j}(d) x_{j}-\bar{x} \sum_{j=1}^{n} w_{i j}(d)}{S \sqrt{\frac{n \sum_{J=1}^{n} w_{i j}^{2}(d)-\left(\sum_{j=1}^{n} w_{i j}(d)\right)^{2}}{n-1}}}
$$

Positive and negative values for the Getis-Ord Gi* statistic represent clusters of crashes with high- and lowvalue events, respectively [61]. In this study, the GetisOrd $\mathrm{Gi}^{*}$ statistic was used to identify clusters of high values (hotspots) and clusters of low values (coldspots) of alcohol-related crash and KSI rates before and after the introduction of Uber in Santiago, Chile. Hotspots and coldspots were detected for three confidence levels (90, 95, and 99\%).

\section{Risk ratios and random-effects meta-analysis}

To complement our spatial statistical analysis, we also assessed alcohol-related crash variations by calculating risk ratios (RR) with 95\% confidence intervals (CI) [62] at three levels: municipality, municipality socioeconomic groups, and Santiago. For this, we first determined the risk of experiencing an alcohol-related crash and KSI dividing each of these two outcomes by the population in each municipality. Second, to determine each RR, we divided the risk obtained after Uber's entry by the risk before Uber's entry. An RR equal to 1.0 indicates no difference risks among Uber's pre- and post-periods, whereas an RR lower (higher) than 1.0 suggests a lower (higher) risk after the presence of Uber. Third, to obtain a RR for each municipal socioeconomic group and one for the whole city, we applied random-effects metaanalysis by pulling the RR obtained from each municipality [63]. Random-effects were chosen since it is assumed that Uber trips were not equal among municipality socioeconomic groups. To deal with zero cells, we applied the Peto method [64], which can provide robust pooled estimates when information of specific unit of analysis is absent [65]. This strategy is adequate to determine overall changes either at the city level or at each municipality socioeconomic group. We formally tested a possible gradient across municipality socioeconomic groups using meta-regression analysis [66]. All spatial and statistical analyses were performed using ArcGIS 10.5 and Stata 16 software, respectively.

\section{Results}

In Table 1, we observe the distribution of both all alcohol-related crashes and KSI-alcohol-related population rates for the period of analysis. Before Uber, all alcohol-related crashes and KSI-alcohol-related rates per 100,000 population are equal to 9.08 and 1.63 , respectively, whereas after the introduction of Uber both rates are equal to 10.23 and 1.65 , respectively.

Figures 1-4 show spatial clustering of alcohol-related crashes and KSI rates during the period before and after the entry of Uber using the Getis-Ord Gi* statistic. Only hotspots (i.e., intense clustering of high values) are observed for different confidence levels in these figures, and thus, no coldspots (i.e., intense clustering of low values) were identified in the spatial statistical analysis. Figure 1 suggests that only the municipality of Puente Alto (middle SES) persisted as a hotspot of the total number of crashes with a 99\% confidence level after Uber's entry. Whereas Vitacura (high SES), Ñuñoa (High SES), Santiago (high-middle SES), and La Florida (highmiddle SES) were no longer hotspots after the presence of Uber. Figure 2 suggests that Vitacura (high SES) persists over time as a hotspot when the analysis considers the number of crashes per 100,000 population. The municipalities of Nuñoa (high SES) and La Cisterna (highmiddle SES) were no longer hotspots in the period in which Uber emerges, but Quinta Normal (middle SES) and Lo Barnechea (high SES) arose as new hotspots in that period.

Hotspots for KSI outcomes were also mixed. Figure 3 suggests that Vitacura (high SES), Las Condes (high SES) and Santiago (high-middle SES) appeared as hotspots of KSI before Uber's entry. In the period of Uber's entry, only Vitacura (high SES) continued as a hotspot, but Santiago (high-middle SES) and Las Condes (high SES) were no longer hotspots. In the second period, San Bernardo (low-middle SES) and Puente Alto (middle 
Table 1 All alcohol-related crashes, and killed and seriously injured alcohol-related victims per 100,000 population before (JanSeptember 2013) and with (Jan-September 2014) Uber in Santiago, Chile

\begin{tabular}{lll}
\hline Outcomes & Period of analysis & \\
\cline { 2 - 3 } & $\begin{array}{l}\text { Pre-Uber January 1st September } \\
\text { 16th, 2013 }\end{array}$ & $\begin{array}{l}\text { With Uber January 1st September } \\
\mathbf{1 6 t h}, \mathbf{2 0 1 4}\end{array}$ \\
\hline $\begin{array}{l}\text { All alcohol-related crashes per 100,000 population } \\
\begin{array}{l}\text { Killed and seriously injured alcohol-related victims per 100,000 } \\
\text { population }\end{array}\end{array}$ & 9.08 & 10.23 \\
\hline
\end{tabular}

SES) emerged as new hotspots. Figure 4 shows that Vitacura (high SES) persisted as a hotspot of the number of KSI per 100,000 population after Uber, but San Miguel (high-middle SES) was no longer a hotspot. The municipalities of Huechuraba (middle SES) and Quinta Normal (middle SES) emerged as new hotspots when Uber was launched in the city. Overall, these results do not show a consistent association between Uber's pre- and postperiods and the observed alcohol-related crash variation. We obtained very similar results when we carried out analyses using vehicle fleet as denominator (Please refer to Figures SF1 and SF2).

Figures 5 and 7 show RR for alcohol-related crash and KSI at the municipality level, pooled RR estimates by SES and the overall pooled RR estimate, respectively. Figures 6 and 8 display bubble plots of alcohol-related crashes RR and KSI, respectively, with fitted meta regression lines across municipality socioeconomic groups.

First, regarding alcohol-related crashes and Uber (Fig. 5), we observe a RR of 1.10 (95\% C.I. 0.97, 1.27) for the overall association. This confirms the overall results of spatial analysis. Second, the high-high and highmiddle groups are associated with RR of 0.71 (95\% C.I. $0.56,0.89$ ) and 0.39 (95\% C.I. 0.29, 0.52), respectively. The middle, low-middle, and low socioeconomic municipality groups have RRs higher than 1 . Within the high-high group, Vitacura, Las Condes, and Nuñoa have RRs of 0.61 (95\% C.I. 0.38, 0.93), 0.18 (95\% C.I. 0.07, 0.44 ) and 0.57 (95\% C.I. 0.39, 0.84), respectively, and within the high-middle group, the municipalities of Santiago and La Cisterna have RRs in the same direction with 0.23 (95\% C.I. 0.14, 0.38) and 0.14 (95\% C.I. 0.06, $0.29)$, respectively. These results are partially aligned with the spatial analysis since similar tendencies were observed in Nuñoa, Santiago, and La Cisterna. The clustering of RR by socioeconomic groups suggests a mild decrease gradient after the presence of Uber. The distribution of these results is captured in Fig. 6, in which the bubbles representing the RR of each municipality by SES show an inverse association after the introduction of Uber. The higher the SES of the municipality, the higher the reduction of alcohol related traffic outcomes.

Figure 7 confirms an overall no significant association in the city of Santiago between Uber and KSI variation as suggested in the spatial analysis. First, we observe a RR of 0.98 (95\% C. I $0.73,1.31)$ for the overall estimate. Second, regarding socioeconomic groups, the high-high and high-middle groups are associated with RRs of 0.75 (95\% C.I. $0.43,1.31$ ) and 0.17 (95\% C.I. 0.08, 0.38), respectively, whereas middle, low-middle, and low groups

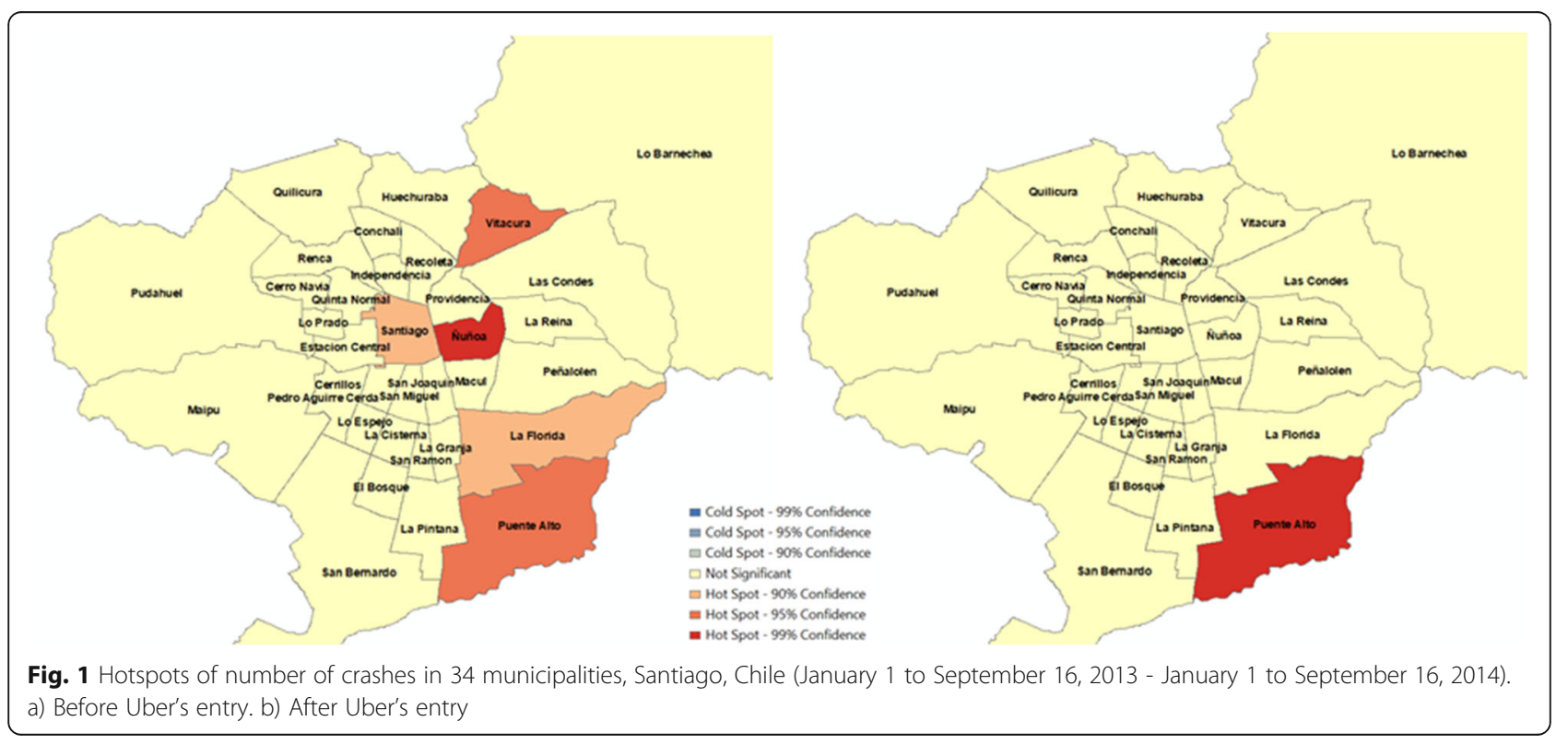




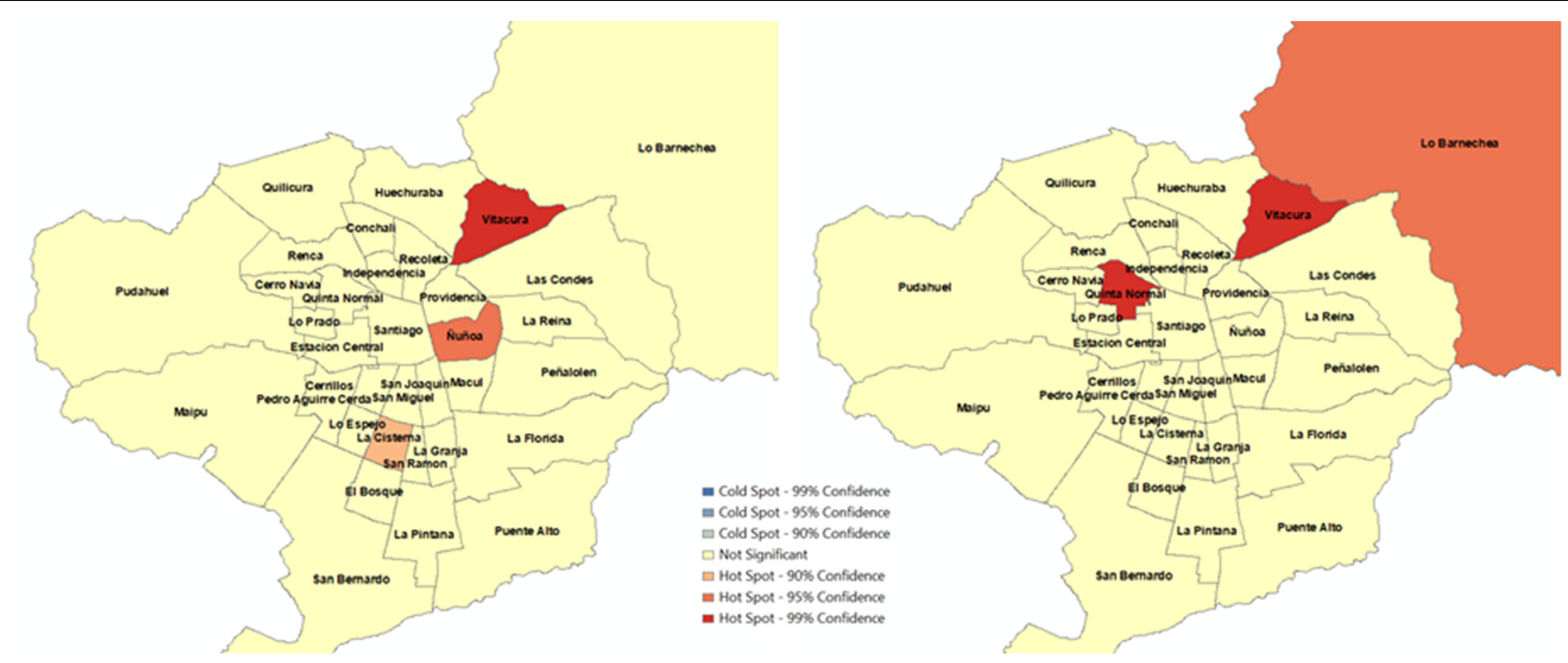

Fig. 2 Hotspots of number of crashes per 100,000 population in 34 municipalities, Santiago, Chile (January 1 to September 16, 2013 - January 1 to September 16, 2014). a) Before Uber's entry. b) After Uber's entry

have RRs higher than 1. Third, municipalities Las Condes, Santiago, and San Miguel have the lowest RRs with 0.12 (95\% C.I. 0.03, 0.47), 0.06 (95\% C.I. 0.02, 0.20) and 0.11 (95\% C.I. 0.03, 0.47), respectively, and Huechuraba and San Bernardo are the only municipalities with positive and significant RRs of 6.06 (95\% C.I. 1.21, 30.30) and 4.60 (95\% C.I. 1.47, 14.30), respectively. Similarly, to alcohol-related crashes outcomes, there is a mild gradient across socioeconomic groups. Figure 8 confirms these observations, since the higher the socioeconomic classification of the municipality, the higher the reduction in the selected outcome. In short, the overall decline is pulled by municipalities classified as high and highmiddle SES.

\section{Discussion}

In Santiago, Chile, the first 260 days of ridesharing does not seem to be associated with variations on alcoholrelated collisions per 100,000 population. However, this twofold analysis, considering 34 municipalities, suggests that in locations where residents with high SES live, the introduction of Uber could have had a mild protective effect, whereas in more vulnerable municipalities no effects and even increases in alcohol-related collisions were observed. The magnitude of prevention in municipalities, which disproportionally have the richest population, were associated with decreases of $29 \%$ in all alcohol-related collisions and a non-significant decrease of $25 \%$ in KSI outcomes. In the most disadvantageous

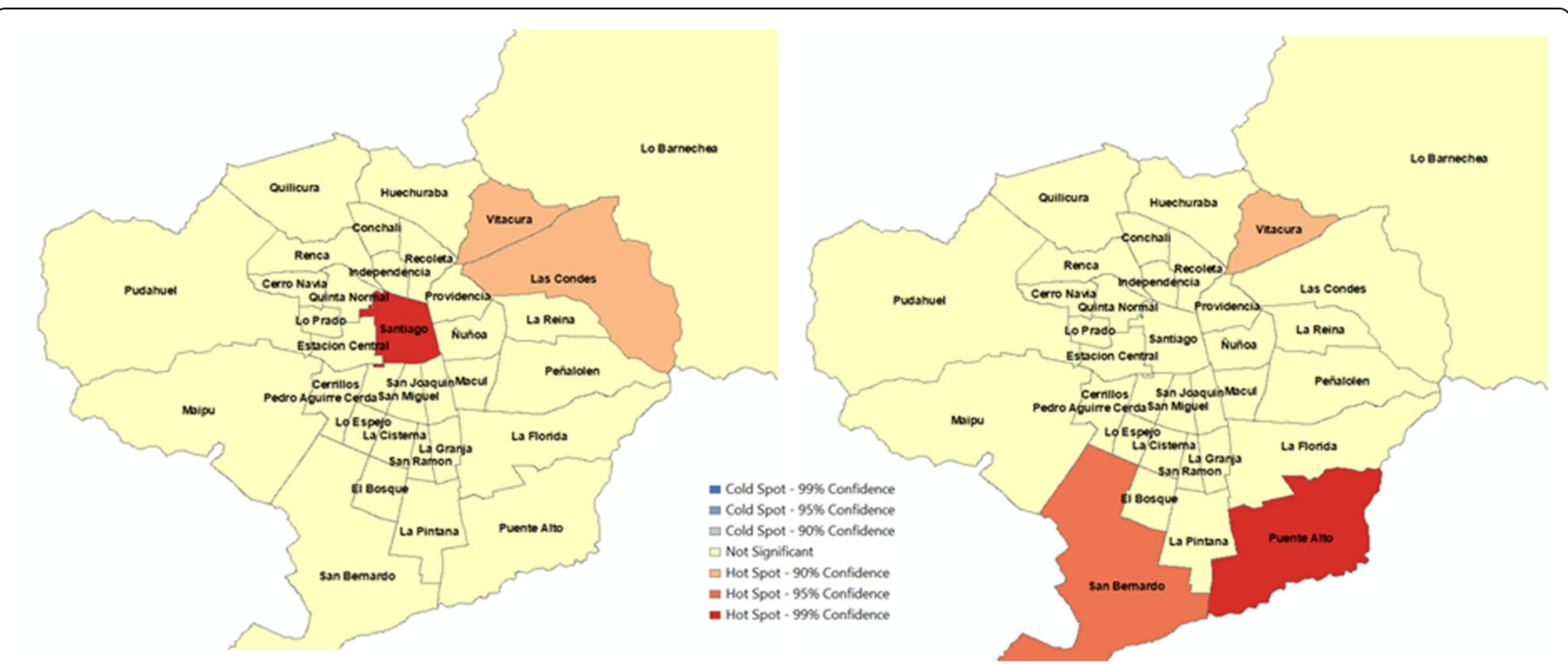

Fig. 3 Hotspots of number of KSI in 34 municipalities, Santiago, Chile (January 1 to September 16, 2013 - January 1 to September 16, 2014). a) Before Uber's entry. b) After Uber's entry 


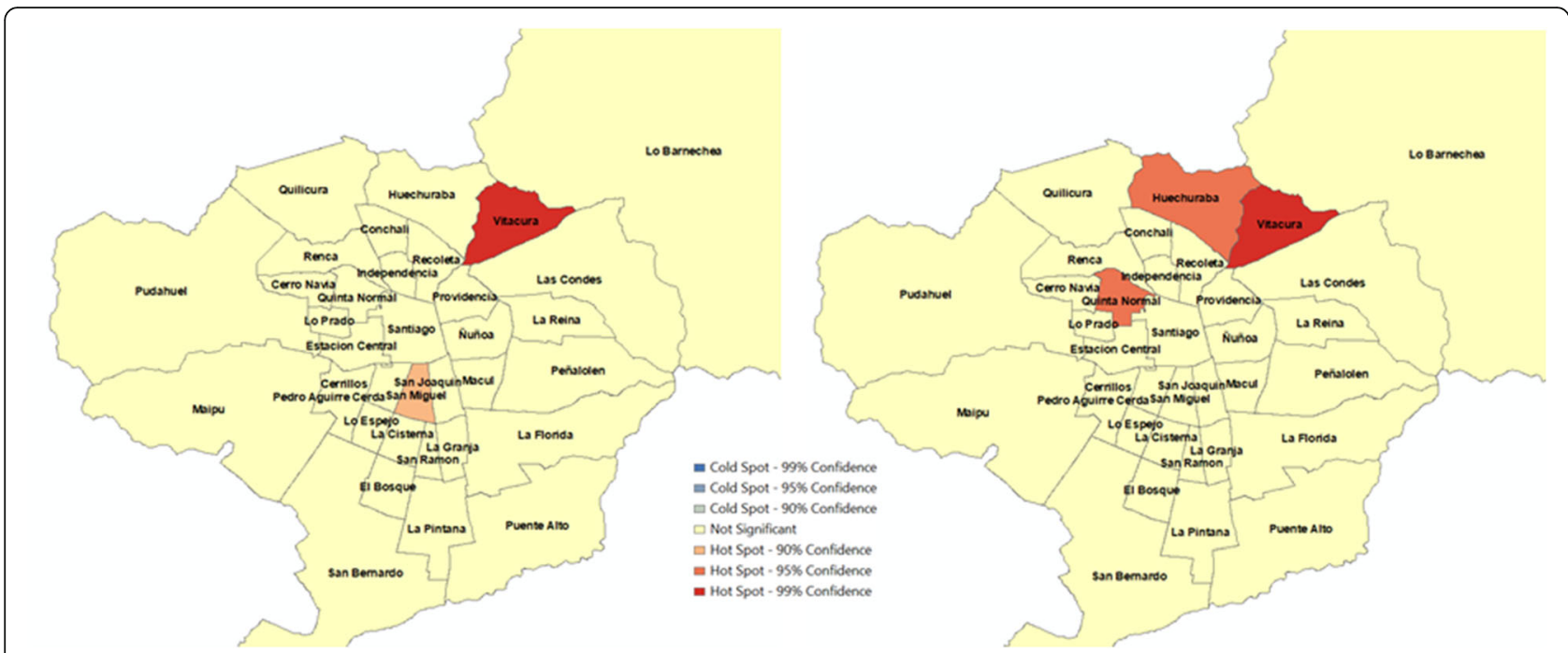

Fig. 4 Hotspots of number of KSI per 100,000 population in 34 municipalities, Santiago, Chile (January 1 to September 16, 2013 - January 1 to September 16, 2014). a) Before Uber's entry. b) After Uber's entry

zones, non-significant alcohol-related collisions increases of $20 \%$ but significant increases by three times in KSI were respectively observed.

The overall result of this study is in line with a previous study [36]. Nevertheless, the direction and magnitude of the present study is different. Whereas NazifMunoz et al. [36] found a non-significant decrease of
$28 \%$ in alcohol-related collisions, in this study a nonsignificant $10 \%$ increase in the outcomes were observed. Differences across these two studies may be signalling variations between pre- and post-Uber terms used. Whereas the first study considered two and 1 years, respectively, in this one, the analysis was restricted to 9 months for each period. Results from the spatial analysis

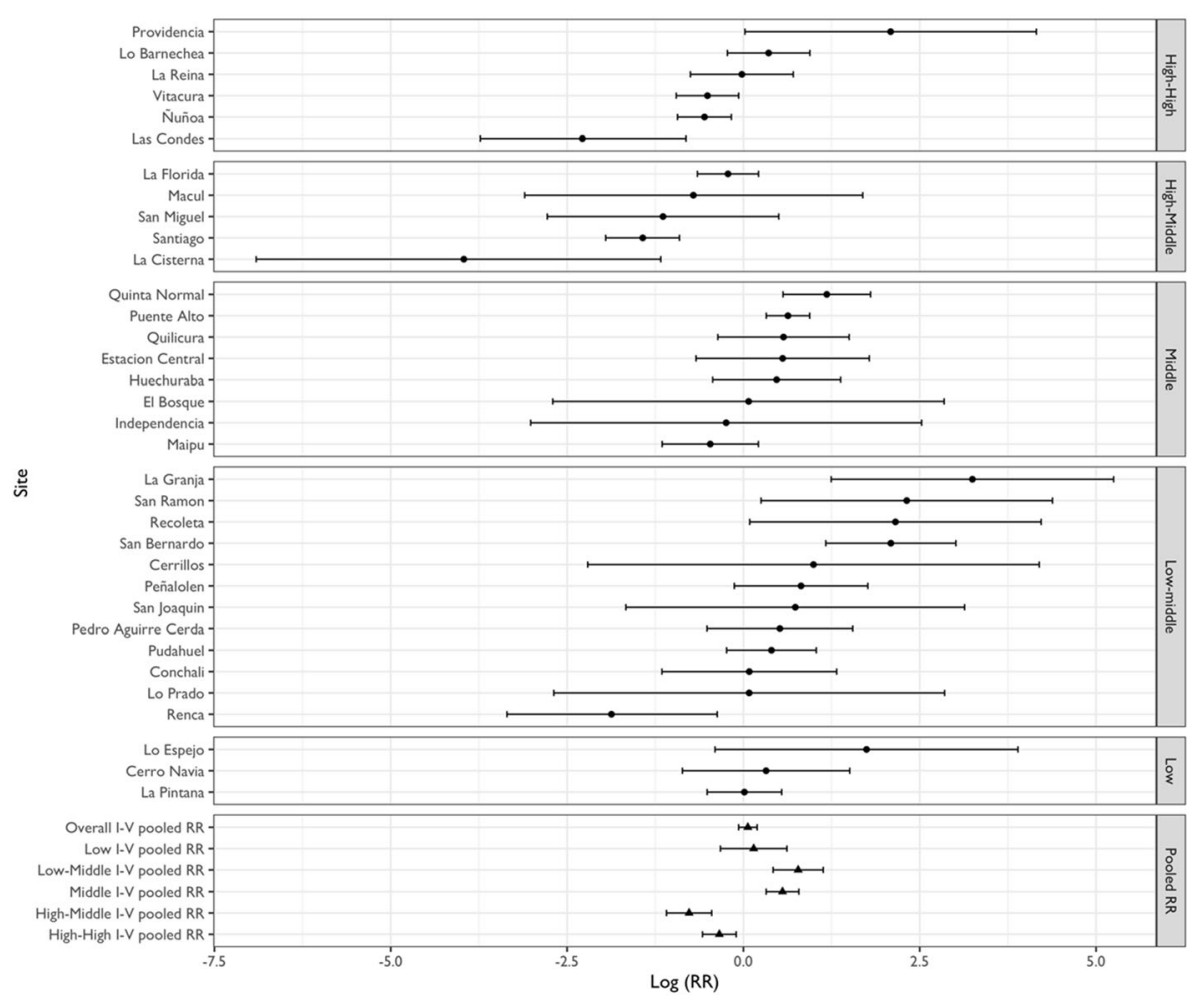

Fig. 5 Association between alcohol-related crashes and absence and presence of Uber summarized by municipality socioeconomic groups 


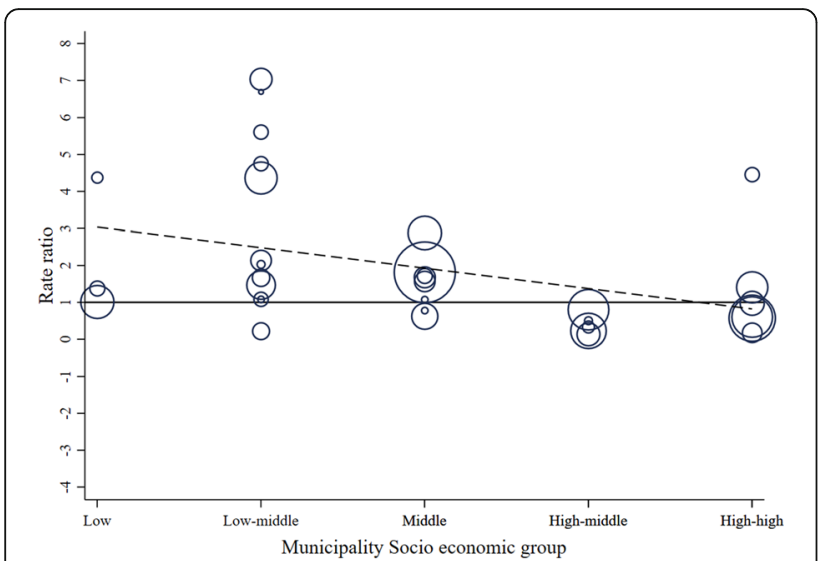

Fig. 6 Bubble plot of alcohol-related crashes rate ratios with fitted meta regression line across municipality socio economic groups

suggested that over time there are indeed differences across municipalities, which may have been masked when city is used as unit of analysis.

Assuming that ridesharing in its inception would penetrate high socioeconomic zones more rapidly, we hypothesized that Uber would have a protective effect in reducing alcohol-related outcomes in these areas. We specifically suggested that early adopters of ridesharing would have more opportunities to overcome the dilemma of drinking and driving since reaching an alternative means of private transport becomes more feasible when both a cell phone application and a credit card are available, and the ridesharing rates are affordable. This is reaffirmed when we concentrate on Las Condes and Vitacura. These two municipalities concentrate more than $63 \%$ of the individuals in the highest income quintile [67] and on average have the highest income per capita in Santiago [68]. Indeed, results of the spatial analysis suggests that Vitacura (Fig. 1) and Las Condes (Fig. 3) are no longer hotspots for the period when Uber emerges. Further, our RR suggest concomitant decreases by 29 and $82 \%$ in all alcohol-related collisions (Fig. 5), respectively. This socioeconomic gradient is indirectly confirmed with the associations observed across municipalities (Fig. 6). Possibly, alternative modes of transport such as ridesharing were not available because individuals living in these areas were structurally prevented to not having access to it since credit card was a required condition to use Uber.

The observed variability in the estimated relationships across municipalities before and after ridesharing was introduced may be however due to other circumstances, for instance, different levels of access to alcohol or alcohol consumption, police enforcement practices, and road infrastructure. Several studies conducted in Santiago [46, $69,70]$ have suggested that income is not associated with increments in alcohol consumption. In fact, this

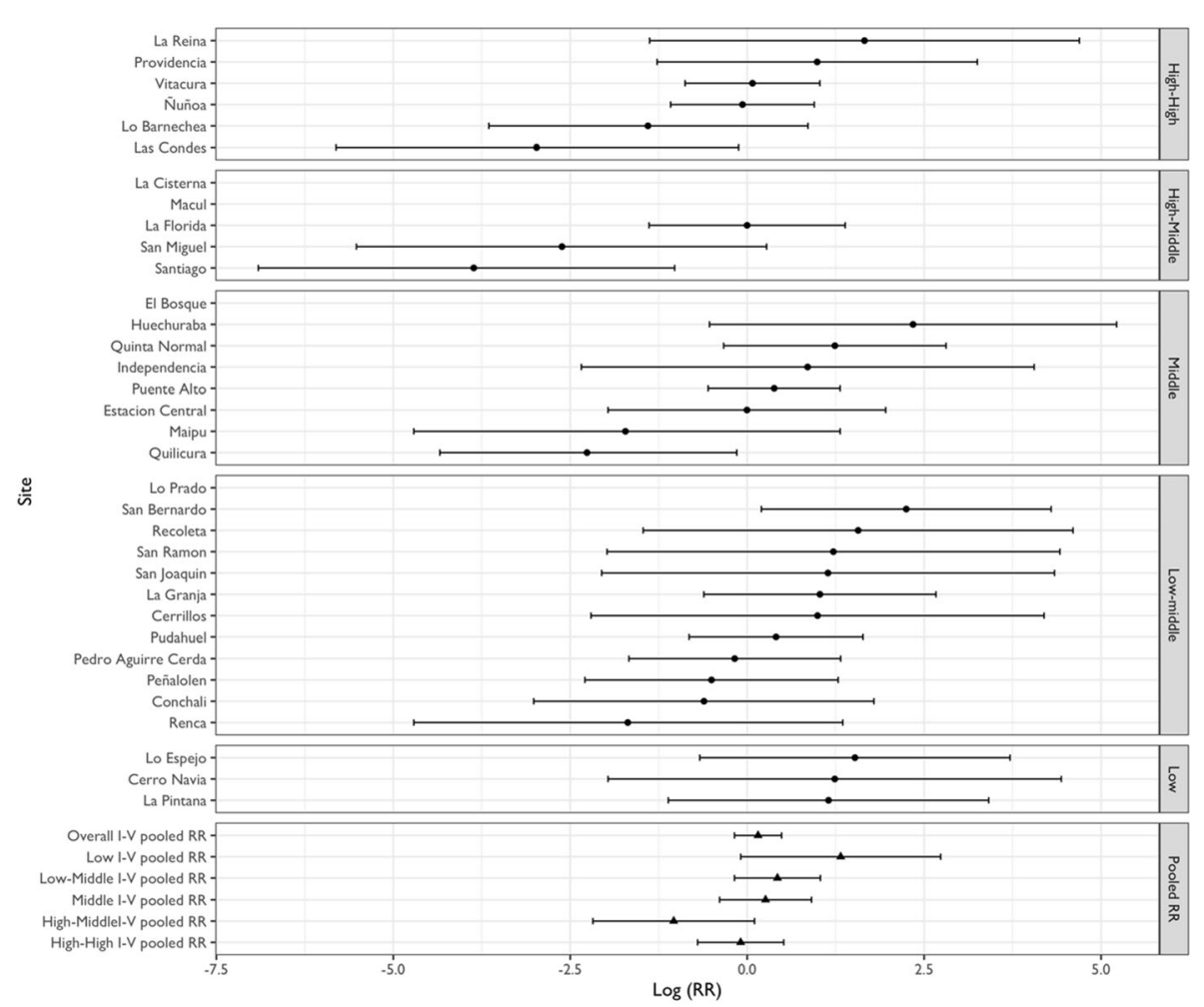

Fig. 7 Association between KSI alcohol-related crashes and absence and presence of Uber summarized by municipality socioeconomic groups 


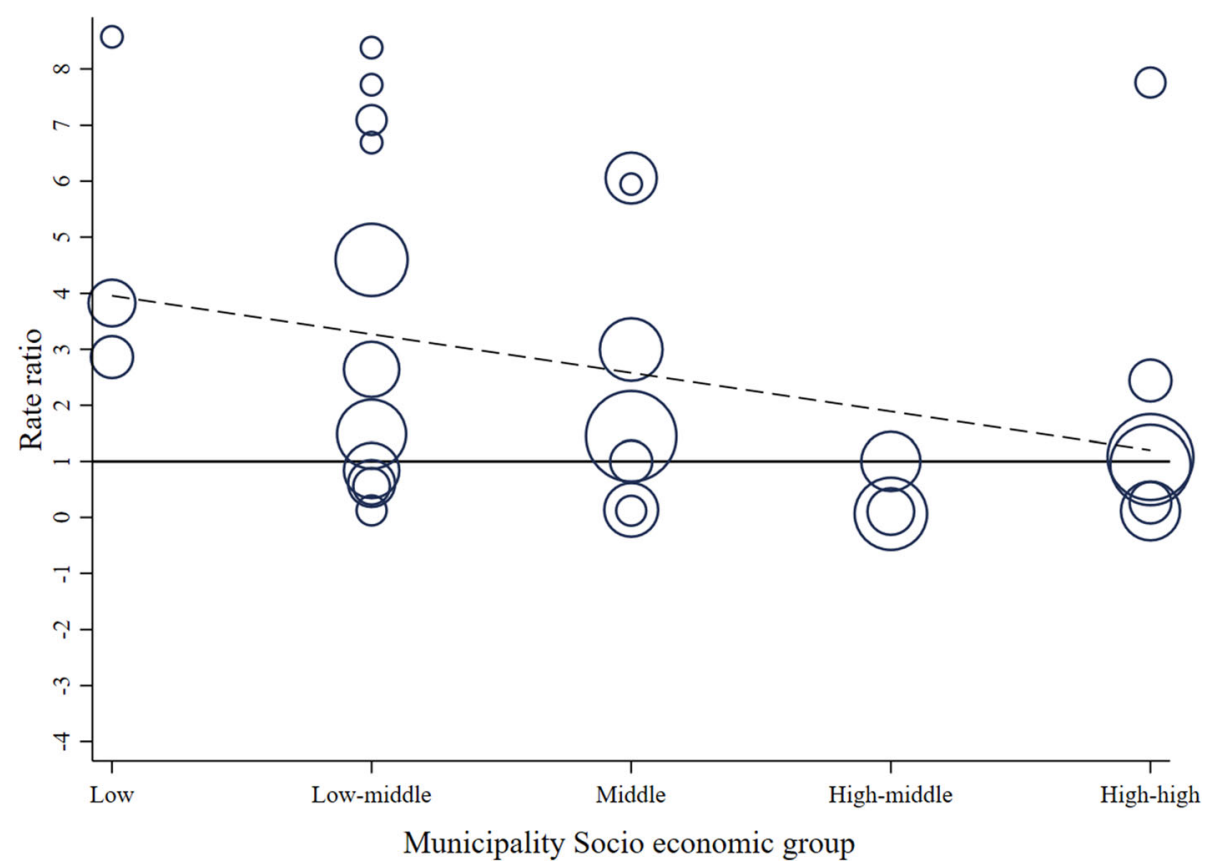

Fig. 8 Bubble plot of alcohol-related crashes KSI rate ratios with fitted meta regression line across municipality socio economic groups

has been noted using three different representative surveys, the Santiago Longitudinal Study, the National Health Survey 2009-2010, and the Family Budget Survey. As such, part of the decrease of alcohol-related collisions in high-income municipalities may not be attributed to decreases in alcohol consumption if no evidence so far points to this direction. However, increases in alcohol-related crashes in low socioeconomic municipalities could be associated with more access to unauthorized alcohol sales in these zones. Surveys in Chile suggest that perception of unauthorized alcohol sales in low socioeconomic municipalities have increased from $17.8 \%$ in 2012 to $23.7 \%$ in 2014 [ 71,72 ]. In terms of police enforcement, spatial analysis of police stations within Santiago suggests a nonlinear socioeconomic distribution of access to police services [73]. Both lower and higher income groups are more likely to have less access to polices services than middle income groups. This may particularly explain the high RR of San Bernardo, but it is not adequate to understand why we observed over the period analysed a decrease in highincome municipalities and an increase in low-income municipalities. It is important to highlight that even though a no clear association across municipality socioeconomic groups and enforcement is observed in Santiago, there is also evidence that police enforcement within the same low socioeconomic groups may have very different practices, such as surveillance or detentions [74]. Whereas adequate police protection is consistently perceived in certain low socioeconomic neighbourhoods while in other zones this practice is not even present. This study suggests that low socioeconomic municipalities with high social capital have better communication with police officers, which in turn may affect the increment of policing in these territories [74]. Lastly, there are studies pointing that in Santiago in the last 10 years, transport infrastructure investment has indeed benefited individuals from the top quintiles [7577]. Further, analyses considering the period 2000-2008 in Santiago suggested that the accumulation of specific crashes can be grouped within low quality infrastructure municipalities, however, these are not necessarily in the lowest income quintiles [76]. Changes in transport infrastructure could indeed be signalling decreases in KSI outcomes rather than all alcohol-related per se. One could assume that an increment of forgiving roads designed to decrease the severity of crashes in advantageous municipalities is likely a factor when explaining KSI differences across municipalities. However, this alternative explanation is not sufficient to understand all alcohol-related crashes because preventing alcohol behaviour is not a direct objective of infrastructure changes, but rather a function of enforcement, better transport alternatives, or alcohol availability [78].

There were several limitations to our approach. First, police assessment of alcohol involvement and classification of injuries and fatalities may not be consistent over time, and this measurement error might bias results. Second, it has been found that police officers, in Santiago, carry out identity controls more often to 
individuals from low socioeconomic groups than from high socioeconomic groups [79], and this practice can influence time to arrival to crash scenes biasing the results. Third, although we selected a period in which Uber operations were slowly increasing, we did not have continuous measures of rideshare utilization (e.g., counts of Uber journeys per municipality), much less whether the demand of this service varied by passenger's income. These missing elements would help to better understand the relation between ridesharing and alcohol-related crashes. Last, we cannot rule out the potential for unmeasured time-varying confounding, and particularly the potential for other coincident externalities such as changes in gas prices, which affect overall mobility to impact rates of alcohol-related crash fatalities and injuries. In Santiago, there are considerable gas price differences across gas stations (for instance, more than $10 \%$ of difference can be found) [80], which affect the conditions of how individuals mobilize.

\section{Conclusions}

This study highlights that to clearly understand the association between ridesharing (e.g., Uber) and alcoholrelated crashes, attention to who its users are and where they live, and travel needs to be more carefully examined. This association, as such, is likely to differ across municipalities and over time depending on how many individuals increasingly adopt and use this technology vis-à-vis other existent transport alternatives when faced with the drinking and driving dilemma. Future studies should thus seek to identify the key aspects of these differential relationships considering characteristics of ridesharing users as well as the incorporation of other means of payment such direct cash. This study concludes that some technological changes can indeed be important platforms to protect populations exposed to negatives consequences associated with drinking and driving, but part of their success depends on how rapidly they expand. Nevertheless, more rigorous empirical studies should provide clearer explanations on how this novel technology becomes protective when passengers opt for it.

\section{Supplementary Information}

The online version contains supplementary material available at https://doi. org/10.1186/s12889-021-12066-z.

Additional file 1: Table S1. Municipality by socioeconomic group classification. Fig. S1. Hotspots of number of crashes per 10,000 registered vehicles. Fig. S2. Hotspots of number of KSI per 10,000 registered vehicles.

\section{Acknowledgements}

We would like to acknowledge Isadora Hochfärber and Maurizio Amaro for their work on crash data preparation and analysis.

\section{Authors' contributions}

$\mathrm{CB}$, JGCL and JINM designed the study. CB collected the crash data, and CB carried out the spatial analysis including the spatial figures. JINM conducted the statistical analysis. JGCL developed rate ratio figures. JINM wrote the first draft, and $C B$, JGCL, and JINM contributed to revisions and final writing of the manuscript. All author(s) read and approved the final manuscript.

\section{Funding}

JINM was founded by the Fonds de recherche du Québec - Santé Programme Chercheurs-boursiers - Junior, and the Social Sciences and Humanities Research Council-Insight Grants; and CB was funded by the Universidad Andres Bello (Project No DI-01-20/REG).

\section{Availability of data and materials}

The datasets used and/or analysed during the current study available from the corresponding author on reasonable request.

\section{Declarations}

Ethics approval and consent to participate

Not applicable because private information is not required to proceed with the statistical analyses applied.

\section{Consent for publication}

Not applicable.

\section{Competing interests}

Not applicable

\section{Author details}

'Department of Engineering Sciences, Universidad Andres Bello, Quillota 980, Viña del Mar, Chile. ${ }^{2}$ Department of Environmental Health, Harvard T.H. Chan School of Public Health, 677 Huntington Avenue, Boston, MA 02115, USA.

${ }^{3}$ Université de Sherbrooke, Faculté de médecine et des sciences de la santé, 150, place Charles-Le Moyne, Longueuil, QC J4K OA8, Canada.

Received: 25 March 2021 Accepted: 14 October 2021

Published online: 04 November 2021

\section{References}

1. Uber. Uber cities. 2020. https://www.uber.com/global/en/cities/. Accessed 10 Jan 2021.

2. Chaudhry B, Yasar A-U-H, El-Amine S, Shakshuki E. Passenger safety in ridesharing services. Procedia Comput Sci. 2018;130:1044-50. https://doi.org/1 0.1016/j.procs.2018.04.146.

3. Xie Y, Danaf M, Lima Azevedo C, Akkinepally AP, Atasoy B, Jeong K, et al. Behavioral modeling of on-demand mobility services: general framework and application to sustainable travel incentives. Transportation (Amst). 2019; 46(6):2017-39. https://doi.org/10.1007/s11116-019-10011-z.

4. Rogers E. Diffusion of innovations. 5th ed. New York: Simon and Schuster; 2010.

5. Valente TW, Rogers EM. The origins and development of the diffusion of innovations paradigm as an example of scientific growth. Sci Commun. 1995;16(3):242-73. https://doi.org/10.1177/1075547095016003002.

6. Valente TW, Vega Yon GG. Diffusion/contagion processes on social networks. Health Educ Behav. 2020;47(2):235-48. https://doi.org/10.1177/1 090198120901497.

7. Valente TW. Social network thresholds in the diffusion of innovations. Soc Networks. 1996;18(1):69-89. https://doi.org/10.1016/0378-8733(95)00256-1.

8. Zsifkovits $M$, Günther M. Simulating resistances in innovation diffusion over multiple generations: an agent-based approach for fuel-cell vehicles. Cent Eur J Oper Res. 2015;23(2):501-22. https://doi.org/10.1007/s10100-015-0391$x$.

9. Talebian A, Mishra S. Predicting the adoption of connected autonomous vehicles: a new approach based on the theory of diffusion of innovations. Transp Res Part C Emerg Technol. 2018:95:363-80. https://doi.org/10.1016/j. trc.2018.06.005.

10. Wang Y, Douglas MA, Hazen BT, Dresner M. Be green and clearly be seen: how consumer values and attitudes affect adoption of bicycle sharing. Transp Res Part F Traffic Psychol Behav. 2018;58:730-42. https://doi.org/10.1 016/j.trf.2018.06.043. 
11. Mallat N, Rossi M, Tuunainen VK, Öörni A. An empirical investigation of mobile ticketing service adoption in public transportation. Pers Ubiquitous Comput. 2007;12(1):57-65. https://doi.org/10.1007/s00779-006-0126-z.

12. Manca F, Sivakumar A, Polak JW. The effect of social influence and social interactions on the adoption of a new technology: the use of bike sharing in a student population. Transp Res Part C Emerg Technol. 2019;105:611-25. https://doi.org/10.1016/j.trc.2019.02.010.

13. Jansson J, Pettersson T, Mannberg A, Brännlund R, Lindgren U. Adoption of alternative fuel vehicles: influence from neighbors, family and coworkers. Transp Res D Transp Environ. 2017;54:61-73. https://doi.org/10.1016/j.trd.201 7.04.012.

14. Martin A, Lagarde E, Salmi LR. Burden of road traffic injuries related to delays in implementing safety belt laws in low-and lower-middle-income countries. Traffic Inj Prev. 2018;19(sup 1):1-6.

15. Nazif-Muñoz Jl. Did child restraint laws globally converge? Examining 40 years of policy diffusion. Traffic Inj Prev. 2015;16 Suppl 2(sup2):S32-40.

16. Rezvani Z, Jansson J, Bodin J. Advances in consumer electric vehicle adoption research: a review and research agenda. Transp Res D Transp Environ. 2015;34:122-36. https://doi.org/10.1016/.j.trd.2014.10.010.

17. Carpenter CS, Stehr M. The effects of mandatory seatbelt laws on seatbelt use, motor vehicle fatalities, and crash-related injuries among youths. $J$ Health Econ. 2008;27(3):642-62. https://doi.org/10.1016/j.jhealeco.2007.09.01 0.

18. Sen A, Mizzen B. Estimating the impact of seat belt use on traffic fatalities: empirical evidence from Canada. Can Public Policy. 2007;33(3):315-35. https://doi.org/10.3138/cpp.33.3.315.

19. Brubacher JR, Desapriya E, Erdelyi S, Chan H. The impact of child safety restraint legislation on child injuries in police-reported motor vehicle collisions in British Columbia: an interrupted time series analysis. Paediatr Child Health. 2016;21(4):e27-31. https://doi.org/10.1093/pch/21.4.e27.

20. Geroski PA. Models of technology diffusion. Res Policy. 2000;29(4-5):603-25. https://doi.org/10.1016/S0048-7333(99)00092-X

21. Zhang $Y$, Zhang $Y$. Exploring the relationship between ridesharing and public transit use in the United States. Int J Environ Res Public Health. 2018; 15(8) Available from:. https://doi.org/10.3390/ijerph15081763.

22. Rayle L, Dai D, Chan N, Cervero R, Shaheen S. Just a better taxi? A surveybased comparison of taxis, transit, and ridesourcing services in San Francisco. Transp Policy (Oxf). 2016:45:168-78.

23. Dias FF, Lavieri PS, Garikapati VM, Astroza S, Pendyala RM, Bhat CR. A behavioral choice model of the use of car-sharing and ride-sourcing services. Transportation (Amst). 2017;44(6):1307-23. https://doi.org/10.1007/s11116-017-9797-8.

24. Alemi F, Circella G, Mokhtarian P, Handy S. What drives the use of ridehailing in California? Ordered probit models of the usage frequency of Uber and Lyft. Transp Res Part C Emerg Technol. 2019;102:233-48. https:// doi.org/10.1016/j.trc.2018.12.016.

25. Conway MW, Salon D, King DA. Trends in taxi use and the advent of ridehailing, 1995-2017: evidence from the US National Household Trave Survey. Urban Sci. 2018;2(3):79. https://doi.org/10.3390/urbansci2030079.

26. Carmody P, Fortuin A. "Ride-sharing", virtual capital and impacts on labor in Cape Town, South Africa. Afr Geogr Rev. 2019;38(3):196-208. https://doi. org/10.1080/19376812.2019.1607149.

27. Schechtner K, Hanson M. Shared mobility in Asian megacities: the rise of the apps. In: Disrupting Mobility. Cham: Springer International Publishing; 2017. p. 77-88. https://doi.org/10.1007/978-3-319-51602-8_5.

28. Wang $Y$, Zheng B, Lim EP. Understanding the effects of taxi ride-sharing-a case study of Singapore. Comput Environ Urban Syst. 2018;69:124-32. https://doi.org/10.1016/j.compenvurbsys.2018.01.006.

29. Hall JD, Palsson C, Price J. Is Uber a substitute or complement for public transit? J Urban Econ. 2018;108:36-50. https://doi.org/10.1016/j.jue.2018.09. 003.

30. Laakso S. Giving up cars-the impact of a mobility experiment on carbon emissions and everyday routines. J Clean Prod. 2017;169:135-42. https://doi. org/10.1016/j.jclepro.2017.03.035.

31. Brazil N, Kirk DS. Uber and metropolitan traffic fatalities in the United States. Am J Epidemiol. 2016;184(3):192-8. https://doi.org/10.1093/aje/kww062.

32. Greenwood BN. Temple University, Wattal S, Temple University. Show me the way to go home: an empirical investigation of ride-sharing and alcohol related motor vehicle fatalities. MIS Q. 2017;41(1):163-87. https://doi.org/10.2 5300/MISQ/2017/41.1.08.

33. Peck J. New York City drunk driving after Uber. New York: City University of New York Graduate Center, Ph.D. Program in Economics; 2017.
34. Morrison CN, Jacoby SF, Dong B, Delgado MK, Wiebe DJ. Ridesharing and motor vehicle crashes in 4 US cities: an interrupted time-series analysis. Am J Epidemiol. 2018;187(2):224-32. https://doi.org/10.1093/aje/kw×233.

35. Huang JY, Majid F, Daku M. Estimating effects of Uber ride-sharing service on road traffic-related deaths in South Africa: a quasi-experimental study. . Epidemiol Commun Health. 2019;73(3):263-71. https://doi.org/10.1136/ jech-2018-211006.

36. Nazif-Muñoz Jl, Batomen B, Oulhote Y, Spengler J, Nandi A. State or market? How to effectively decrease alcohol-related crash fatalities and injuries. J Epidemiol Commun Health. 2020;74(6):502-9. https://doi.org/10.1136/jech-2 019-213191.

37. Martin-Buck F.P. Driving safety: an empirical analysis of ridesharing's impact on drunk driving and alcohol-related crime. 2016. Available from: http:// www.frankmartinbuck.com/Ridesharing\%20and\%20Alcohol-Related\%2 oCrime\%20by\%20Frank\%20Martin-Buck.pdf

38. Brazil N, Kirk DS. Ridehailing and alcohol-involved traffic fatalities in the United States: the average and heterogeneous association of uber. PLoS One. 2020;15(9):e0238744. https://doi.org/10.1371/journal.pone.0238744.

39. Dills AK, Mulholland SE. Ride-sharing, fatal crashes, and crime: ride-sharing, fatal crashes, and crime. South Econ J. 2018;84(4):965-91. https://doi.org/1 $0.1002 /$ soej. 12255

40. Young M, Farber S. The who, why, and when of Uber and other ride-hailing trips: an examination of a large sample household travel survey. Transp Res Part A Policy Pract. 2019;119:383-92. https://doi.org/10.1016/j.tra.2018.11.018.

41. EMOL. Uber detecta mayor aumento de viajes entre zonas periféricas y el centro en horarios punta (2017). https://www.emol.com/noticias/Nacional/2 017/03/04/847800/Uber-detecta-mayor-aumento-de-viajes-entre-zonasperifericas-y-el-centro-en-horarios-punta.html Accessed 16 Aug 2021.

42. Tirachini A, Gomez-Lobo A. Does ride-hailing increase or decrease vehicle kilometers traveled (VKT)? A simulation approach for Santiago de Chile. Int J Sustain Transp. 2020;14(3):187-204. https://doi.org/10.1080/15568318.2018.1 539146

43. Tirachini A, del Río M. Ride-hailing in Santiago de Chile: users' characterisation and effects on travel behaviour. Transp Policy (Oxf). 2019;82: 46-57. https://doi.org/10.1016/j.tranpol.2019.07.008.

44. Marambio-Tapia A. Narratives of social mobility in the post-industrial. working class and the use of credit in Chilean households. Rev Régul. 2017; (22) Available from:. https://doi.org/10.4000/regulation.12512.

45. Ministry of Social Development and Family: CASEN, Survey of Household Finances 2017. https://www.desarrollosocialyfamilia.gob.cl/informacion-socia Vencuesta-casen-2017. 2017. Accessed 2 Mar 2021.

46. Peña S, Mäkelä P, Valdivia G, Helakorpi S, Markkula N, Margozzini P, et al. Socioeconomic inequalities in alcohol consumption in Chile and Finland. Drug Alcohol Depend. 2017;173:24-30. https://doi.org/10.1016/j.druga Icdep.2016.12.014.

47. Comisión Nacional de Seguridad de Tránsito, CONASET: Request of Information, Transparency Law. http://www.subtrans.gob.cl/transparencia/ solicitud_informacion.html (n.d). Accessed 23 Aug 2019.

48. Falcone SD. El delito de negativa injustificada de un conductor a someterse a los exámenes de detección de alcohol o sustancias estupefacientes o psicotrópicas. Revista de derecho (Valparaíso). 2015;(44):143-69.

49. Rizzi LI, Fariña P. Alcohol en conducción y su incidencia en la ocurrencia de accidentes de tránsito con víctimas fatales en Chile: falencias en las estadísticas nacionales. Estudios de Transporte. 2014;18(1):3-9.

50. National Institute of Statistics: Census 2017. https://www.censo2017.cl. Accessed 19 Feb 2020.

51. García-Echalar A, Rau T. The effects of increasing penalties in drunk driving laws-evidence from Chile. Int J Environ Res Public Health. 2020;17(21):8103. https://doi.org/10.3390/ijerph17218103.

52. Observatorio de Ciudades UC. Plataforma de visualización ICVU 2020-2011. 2020. https://observatoriodeciudades.com/projects/plataforma-de-visualiza cion-icvu/ Accessed 24 Feb 2021.

53. Flahaut B, Mouchart M, San Martin E, Thomas I. The local spatial autocorrelation and the kernel method for identifying black zones. A comparative approach. Accid Anal Prev. 2003;35(6):991-1004. https://doi. org/10.1016/S0001-4575(02)00107-0.

54. Songchitruksa P, Zeng X. Getis-Ord spatial statistics to identify hot spots by using incident management data. Transp Res Rec. 2010;2165(1):42-51. https://doi.org/10.3141/2165-05.

55. Manepalli U, Bham G, Kandada S. Evaluation of hot spots identification using kernel Kensity estimation (K) and Getis-Ord (Gi*) on I-630. In: 
Proceedings of the $3 \mathrm{rd}$ International conference on road safety and simulation: Transportation Research Board; 2011. p. 17.

56. Scott M, Roy SS, Prasad S. Spatial patterns of off-the-system traffic crashes in Miami-Dade County, Florida, during 2005-2010. Traffic Inj Prev. 2016;17(7): 729-35. https://doi.org/10.1080/15389588.2016.1144878.

57. Blazquez CA, Picarte B, Calderón JF, Losada F. Spatial autocorrelation analysis of cargo trucks on highway crashes in Chile. Accid Anal Prev. 2018; 120:195-210. https://doi.org/10.1016/j.aap.2018.08.022.

58. Ouni F, Belloumi M. Pattern of road traffic crash hot zones versus probable hot zones in Tunisia: a geospatial analysis. Accid Anal Prev. 2019:128:185-96. https://doi.org/10.1016/j.aap.2019.04.008.

59. Shabanikiya H, Hashtarkhani S, Bergquist R, Bagheri N, VafaeiNejad R, AmiriGholanlou M, et al. Multiple-scale spatial analysis of paediatric, pedestrian road traffic injuries in a major city in north-eastern Iran 2015-2019. BMC Public Health. 2020;20(1):722. https://doi.org/10.1186/s12889-020-08911-2.

60. Song L, Li Y, Fan WD, Wu P. Modeling pedestrian-injury severities in pedestrian-vehicle crashes considering spatiotemporal patterns: Insights from different hierarchical Bayesian random-effects models. Anal Methods Accid Res. 2020;28(100137):100137.

61. Getis A, Ord JK. The analysis of spatial association by use of distance statistics. Geogr Anal. 2010;24(3):189-206. https://doi.org/10.1111/j.1538-4 632.1992.tb00261.X.

62. Herbison P, Robertson MC, McKenzie JE. Do alternative methods for analysing count data produce similar estimates? Implications for metaanalyses. Syst Rev. 2015;4(1):163. https://doi.org/10.1186/s13643-015-0144-x.

63. Kontopantelis E, Reeves D. Metaan: random-effects meta-analysis. Stata J. 2010;10(3):395-407. https://doi.org/10.1177/1536867X1001000307.

64. Peto R, Pike MC, Armitage P, Breslow NE, Cox DR, Howard SV, et al. Design and analysis of randomized clinical trials requiring prolonged observation of each patient. II. Analysis and examples. Br J Cancer. 1977;35(1):1-39. https:// doi.org/10.1038/bjc.1977.1.

65. Cheng J, Pullenayegum E, Marshall JK, lorio A, Thabane L. Impact of including or excluding both-armed zero-event studies on using standard meta-analysis methods for rare event outcome: a simulation study. BMJ Open. 2016;6(8):e010983. https://doi.org/10.1136/bmjopen-2015-010983.

66. Harbord RM, Higgins JPT. Meta-regression in Stata. Stata J. 2008;8(4):493519. https://doi.org/10.1177/1536867X0800800403.

67. Fernández I, Manuel-Navarrete D, Torres-Salinas R. Breaking resilient patterns of inequality in Santiago de Chile: challenges to navigate towards a more sustainable city. Sustainability. 2016;8(8):820. https://doi.org/10.3390/ su8080820.

68. Agostini CA, Hojman D, Román A, Valenzuela L. Segregación residencial de ingresos en el Gran Santiago 1992-2002: una nueva aproximación metodológica. Revista EURE-Revista de Estudios Urbano Regionales. 2016; 42(127):159-84.

69. Han Y, Grogan-Kaylor A, Delva J, Xie Y. Estimating the heterogeneous relationship between peer drinking and youth alcohol consumption in Chile using propensity score stratification. Int J Environ Res Public Health. 2014; 11(11):11879-97. https://doi.org/10.3390/ijerph111111879.

70. Araya $\mathrm{D}$, Paraje $\mathrm{G}$. The impact of prices on alcoholic beverage consumption in Chile. PLoS One. 2018;13(10):e0205932. https://doi.org/10.1371/journal. pone.0205932.

71. Ministerio del Interior y Seguridad Pública. Décimo estudio nacional de drogas en población general de Chile, 2012. 2013. https://www.senda.gob. cl/wp-content/uploads/2019/07/Decimo-Estudio-de-Drogas-Pob-General-2 012.pdf Accessed 18 Aug 2021

72. Ministerio del Interior y Seguridad Pública. Décimo segundo estudio nacional de drogas en población general de Chile, 2016. 2017. https://www. senda.gob.cl/wp-content/uploads/2017/12/InformeENPG2016.pdf Accessed 18 Aug 2021

73. Cortés Y. Spatial accessibility to local public Services in an Unequal Place: an analysis from patterns of residential segregation in the metropolitan area of Santiago. Chile Sustainability. 2021;13(2):442. https://doi.org/10.3390/su1302 0442.

74. Celhay PA, Gil D. The function and credibility of urban slums: evidence on informal settlements and affordable housing in Chile. Cities. 2020; 99(102605):102605. https://doi.org/10.1016/j.cities.2020.102605.

75. Tiznado Aitken, IA. Accesibility and affordability impacts on transport-related inequalities and poverty: the case of Santiago, Chile. 2020. https:// repositorio.uc.cl/handle/11534/37859
76. Iglesias V, Giraldez F, Tiznado-Aitken I, Muñoz JC. How uneven is the urban mobility playing field? Inequalities among socioeconomic groups in Santiago de Chile. Transp Res Rec. 2019;2673(11):59-70. https://doi.org/10.11 77/0361198119849588.

77. Basso F, Frez J, Martínez L, Pezoa R, Varas M. Accessibility to opportunities based on public transport GPS-monitored data: the case of Santiago. Chile Travel Behav Soc. 2020;21:140-53. https://doi.org/10.1016/j.tbs.2020.06.004.

78. Naimi TS, Xuan Z, Sarda V, Hadland SE, Lira MC, Swahn MH, et al. Association of state alcohol policies with alcohol-related motor vehicle crash fatalities among US adults. JAMA Intern Med. 2018;178(7):894-901. https://doi.org/10.1001/jamainternmed.2018.1406.

79. Duce M, Lillo RM. Controles de identidad realizados por Carabineros: Una aproximación empírica y evaluativa sobre su uso en Chile. Revista de Estudios de la Justicia. 2020;24(33):167-203. https://doi.org/10.5354/0718-4 735.2020 .57635

80. National Commission of Energy: Sistema de Información en línea de precios de combustibles en estacones de servicio 2021. http://www.bencinaenlinea. cl/web2/buscador.php?region=7. Accessed 2 Mar 2021.

\section{Publisher's Note}

Springer Nature remains neutral with regard to jurisdictional claims in published maps and institutional affiliations.
Ready to submit your research? Choose BMC and benefit from:

- fast, convenient online submission

- thorough peer review by experienced researchers in your field

- rapid publication on acceptance

- support for research data, including large and complex data types

- gold Open Access which fosters wider collaboration and increased citations

- maximum visibility for your research: over $100 \mathrm{M}$ website views per year

At BMC, research is always in progress.

Learn more biomedcentral.com/submissions 